\title{
Tempos e costumes
}

\author{
Harley E. A. Bicas
}

Em ciência, a duração de uma vida ou de uma atuação profissional sempre foi considerada quase nada. Hoje em dia, pela velocidade com que os conhecimentos se renovam e pela grandeza das transformações produzidas, esse intervalo de tempo é perturbador. Mudam hábitos, alteram-se conceitos e até princípios se modificam.

Em Oftalmologia, por exemplo, no pequeno período de uma geração, o que era virtude, retirar um cristalino por inteiro, não rompendo sua cápsula, deixou de sê-lo; e o que era erro (tal rompimento da cápsula e a fragmentação do cristalino) virou recomendação, congressos discutindo a melhor forma de fazêlo. Retina, então, mal se tocava nela, seu descolamento exigindo repousos prolongados, na esperança de que ela pudesse voltar ao lugar antes de cirurgia, e quase sempre (ou talvez por isso) significando cegueira. Hoje a moçada toma a cirurgia de retina quase como coisa de principiante e já faz, em ambulatórios, vitrectomias, um procedimento impensável quando fiz minha Residência em Oftalmologia. Pois isso foi há mais de quarenta anos. E translocações de retina! A córnea era tratada com venerável respeito, o que de certo modo chega a chocar um mais velho, quando ele a vê retalhada, queimada, reposta, para a correção de uma simples miopia.

E (espanto) em pouquíssimos minutos e (mais ainda) satisfatoriamente. Para o glaucoma, havia a pilocarpina (e a eserina) ou a cirurgia. No estrabismo usava-se o catgut 4-0, a abertura conjuntival distante do limbo, um recuo de reto medial nos estrabismos infantis não excedia a $4 \mathrm{~mm}$, as correções eram programadas em duas (ou mais) intervenções cirúrgicas e investia-se, demais, no tratamento ortóptico.

O instrumental de consultórios era relativamente pouco e convencional comparado ao de hoje, e as novas tecnologias não apareciam a cada ano, obrigando a contínuas atualizações. Os Congressos, ou reuniões, e cursos eram raros e as comunicações difíceis. Alguém acredita que para se fazer um telefonema (esse nome ainda era usado) interurbano requeriase o concurso de uma telefonista e demoras de quatro a cinco horas para que a ligação pudesse se completar? E dependendo das distâncias, muito mais...

Não havia planos de saúde. Todos os pacientes, eles próprios, pagavam consultas e os que não podiam pagar recorriam aos hospitais públicos, ou de caridade, como "indigentes". Médicos trabalhavam em seus consultórios, não tinham patrões, nem intermediários, não faziam greve, nem reivindicações, não eram processados.
Talvez se possa dizer que a vida era doce e franca, sem que se soubesse disso...

Além de todas as transformações - não apenas quanto a conhecimentos e procedimentos oftalmológicos, mas também sobre as incríveis e caras "tecnologias de ponta" que nos são quase diariamente apresentadas (e, ainda mais surpreendentemente, logo se mostram obsoletas), a exigibilidade de uma constante atualização (e aí estão os congressos e reuniões praticamente semanais, em todos os cantos do Brasil e do mundo), os convênios e as discussões sobre UCOs, a CBHPM, tabelas e bandas, a ameaça de que a optometria possa ser aceita como atividade independente - essa nossa era da comunicação e de sua velocidade vertiginosa nos traz a novidade da informação dos pacientes.

Esse é um fenômeno diretamente originado da rede mundial de comunicação por computadores, disponibilizando buscas e textos, agilizando interações, facilitando acesso a informações técnicas. E mais, como resultado disso, pacientes chegam a se organizar em comunidades "virtuais" para trocar impressões sobre seus males, discutir tratamentos, apresentar soluções criativas a problemas cotidianos que os afligem, relacionados à doença e que, eventualmente, não ocorrem aos médicos que deles cuidam. Daí podem emergir não só apoios psicológicos na aceitação de dificuldades da doença, como orientações vivenciais e de ordem prática em seus enfrentamentos. Em certos casos, os grupos de discussão ganham estrutura própria, transformando-se em verdadeiras "ongs".

Parece legítimo crer que, como parte das prescrições médicas originadas de uma consulta, também se deva dar ao paciente o acesso a tais informações, como forma de enriquecê-lo com conhecimentos sobre suas afecções e até promoverlhe outros tipos de auxílio para enfrentá-las. Uma proposta muito pouco por nós debatida ou explorada. Há endereços eletrônicos para informações, por exemplo, sobre olho seco (www.lagrima-brasil.org.br), doenças degenerativas da retina (retina@caixapostal.com.br) e outras, que podem ser utilíssimas.

Nessa linha de prováveis conveniências mútuas, na reciprocidade de intercâmbios já antecipada e exigida pelos próprios tempos, a abertura de sessões específicas sobre tais interações modernizaria nossos congressos, abrindo-os às comunidades das que devemos ser guias e guardiões.

Tudo tem um começo. Por que não tentar? 